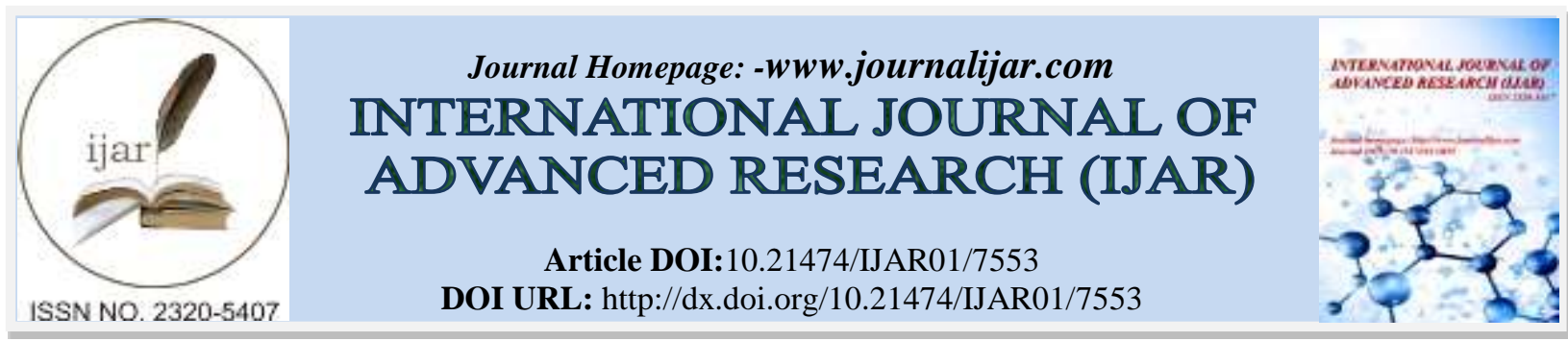

RESEARCH ARTICLE

\title{
ASSESSMENT OF ORGANIQUE MANURE ON GROWTH AND DEVELOPMENT OF 3 PROVENANCES OF MORINGAOLEIFERALAM. IN THE FIELD AT NGAOUNDERE (ADAMAWA, CAMEROON).
}

\section{Zang Emgbang Bénédicte Priscile, Megueni Clautilde, Mapongmetsem Pierre-Marie And Tchuenteu Tatchum Lucien.}

1. Department of Biological Sciences, University of Ngaoundere, P.O. Box 454, Ngaoundere, Cameroon.

2. Biodiversitylaboratory and sustainabledevelopment, University of Ngaoundere, P.O. Box 454, Ngaoundere, Cameroon.

\section{Manuscript Info}

\section{Manuscript History}

Received: 13 June 2018

Final Accepted: 15 July 2018

Published: August 2018

Keywords:-

M. oleifera, provenances, organic manure, performance.

\section{Abstract}

In order to vulgarize and promote moringa cultivation as a basic nutriment against malnutrition, the influence of organic manure was evaluated on the growth and development of different origins of Moringa oleifera in the Guinean savannah highlands of Cameroon. The experimental design was a split-plot with 3 replications. The experimental unit was 30 plants. The type of organic manure (composted dung, dried dung and control) and plant provenances (Far North, North and Adamawa) represented the main and secondary treatments respectively. Results showed an average germination rate of $76.53 \pm 4.35 \%$ and a non-significant difference for both the type of organic manure and the provenances. Provenance has no significant influence $(p>0.05)$ on growth parameters. The fertilizers used significantly influence $(p<0.05)$ the growth parameters as well as the survival rate. Plants enriched with composted cow dung show the best height performance $(26.63 \pm 1.79 \mathrm{~cm})$, neck diameter $(7.11 \pm 0.35 \mathrm{~mm})$ and number of leaves $(10.32 \pm 0.39)$ at 105 days after sowing. Those treated with dried dung has a better survival rate $(75.55 \pm 9.72 \%)$.

Copy Right, IJAR, 2018,. All rights reserved.

\section{Introduction:-}

Worldwide, more than one billion people still live in extreme poverty and suffer from malnutrition (World Bank, 2014). Every year, about seven million people, or $45 \%$ of children, die of famine and the majority of deaths are caused by malnutrition (OMS, 2016). In the context of the global food crisis, the use of local resources such as $M$. oleifera is essential to reduce southern countries' dependence on imported foodstuffs and improve the nutritional status of the poor (Allard, 2009). Indeed, M. oleifera is a species of socio-economic interest (Madiet al., 2012) suitable for local conditions (Fagbuhun et al., 2013). The use of almost all its parts makes it an asset to fight against malnutrition (Malo, 2014, Godinez-Oviedo et al., 2016). It has been identified by the World Vegetable Center as the vegetable with the highest nutritional value among twenty vegetable species (Rayyu et al., 2006). This shrub belonging to Moringaceae'sfamily, is widely used for its preventive and curative properties (Subha and Tapas, 2013). The exploitation of the plant's products makes it possible to improve the diet of the populations and to generate very interesting income for the producers (Rajangamet al., 2001); this is why this plant is called a miracle 
tree (Fulgie, 2001) or a divine plant (Olson, 2001) or a wonderful tree (Kasolo et al., 2010). In many countries, enormous efforts are deployed to vulgarize the use and cultivation of $M$. oleifera for its many assets, including the fight against malnutrition (Barakat and Ghazal, 2016). However, in the Adamawa region of Cameroon, where it is named "Guiligandja" in fufulde, its planting is not very frequent (Njehoya et al., 2014). Its vulgarization and adoption depend on the choice of the appropriate productive varieties and the use of the appropriate fertilizers to intensify its culture, hence the interest of this work. Indeed, an agricultural practice that involves the substantial intake of organic substances, like organic manure, could improve soil fertility (Weber et al., 2007). Organic farming can therefore be a promising approach as it improves production and fertility and respects the environment (Suhag, 2016; Youssef, 2016). The main objective of this study is to contribute to the development of M. oleifera's technical itineraries in Ngaoundéré. Specifically, the effect of organic fertilizer on the growth and development parameters of $M$. oleifera provenances will be assessed, the growth performance of these provenances will be assessed, and their interaction under the ecological conditions of the Guinean savanna highlands of Adamawa in Cameroon.

\section{Material and methods:- \\ Study site:-}

The study was undertaken in the Adamawa region, precisely within the University of Ngaoundéré campus, situated at $15 \mathrm{~km}$ from Ngaoundéré, whose spatial geographical coordinates are the following: Alt:1079 m, LN: $7^{\circ} 24$ ' north latitude and LE:13 ${ }^{\circ} 32$ 'east longitude. This area belongs to Ngaoundéré plateau which has a Guinean climate characterized by two seasons: a dry season from November to March and a rainy season beginning in April and ending in October with rainfall ranging from 900 to $1500 \mathrm{~mm}$ per year. The soils are thick, clay and stay on a ferralistic alteration layer (Rapport OMD, 2010). This area is covered with wooded and shrub savannahs dominated by Danielliaoliveri and Lophiralanceolata (Letouzey, 1968).

\section{Methodology:-}

Three provenances of $M$. oleifera were from: Far North (P1), North (P2) and Adamawa region (P3). Pods were harvested respectively in Maroua, Garoua and Ngaoundéré one month before planting to obtain seeds. Cow dung was taken from Dang in the sub-division of Ngaoundéré III. It was treated in two ways: the first part of the dung was composted (CD) whereas the other part was regularly sun dried (DD). Thus, three types of treatment were applied to each moringa provenances: the control treatment containing no dung (T0), the composted dung treatment (CD) and finally the dried dung (DD) treatment.

The cultivation of $M$. oleifera was carried out in open field over an area of 2 ha previously cleared, grubbed up and then ploughed with a tractor one month before sowing. The field was subdivided into 3 main plots separated by $6 \mathrm{~m}$ wide and $8 \mathrm{~m}$ long aisles. Each parcel contains 9 elementary parcels. The pockets were separeted by $4 \mathrm{~m}$ between the lines and $4 \mathrm{~m}$ between the columns. The experimental design exploited was a split-plot with 3 replications. The main treatment consisted of the type of manure, while the secondary treatment was represented by the different provenances of moringa seeds. The experimental unit made up of 30 pockets per elementary plots.

\section{Crop sowing and maintenance:-}

The seedlings were carried out in June 2016. In each main plot divided into basic plots, the viable seeds of the three origins of $M$. oleifera were sorted out and then soaked in ordinary water for 12 hours according to Tedonkeng et al. (2004). Seeds were sown in pockets about 2 to $3 \mathrm{~cm}$ deep at a rate of 2 to 3 seeds per hole containing $400 \mathrm{~g}$ of amendement according to the requirements of the experimental protocol. The thinning out was done at the end of seedling, after emergence and one plant (the most vigorous) was kept per hole. Maintenance consisted mainly of weeding, every 25 days.

\section{Data collection:-}

Germination rate:-

The seeds were counting every 7 days till 35 days corresponding to the end of seedling emergance throughout the field. The average germination rate (by fertilizer and by source) was evaluated (number of seedlings emerged over the total number of seeds sown) x100 (Ede et al., 2015).

\section{Growth evaluation:-}

After the emergence of the plants, each elementary plot was sampled. Indeed, 10 seedlings randomly selected per treatment were labeled to constitute the population on which growth data were taken. On these seedlings, 
measurements were made on the aerial axis using a scale rule in cm (height), a caliper (diameter) and a manual counting of the leaves every 7 days, till 105 days after sowing (DAS). Plant survival rate was also assessed with Hessou et al. (2013) method.

\section{Data analysis:-}

Each data collected was analyzed for variance. Significant averages were separated using the Duncan Multiple Range Test (DMRT). The software used was Statgraphic plus version 5.0.

\section{Results And Discussion:-}

Germination rate ranged from $74.07 \pm 4.35 \%$ for the control to $79.25 \pm 4.35 \%$ for dried dung treatment (Figure $1 \mathrm{a}$ ). Nonetheless there is no significant difference between fertilizers (P>0.05). In Nigeria, Abdulhamid and Dau (2016) reported similar results with chicken droppings on $M$. oleiferaculture. On the other hand, our results are lower than those of Njehoya et al. (2014) who obtained a germination rate of $96 \%$ on M. oleifera seeds in the Sudano-Guinean zone of Cameroon and higher to those of Yerima et al. (2016) who obtained a rate of 68.7\% atBamenda. The higher germination rate obtained by the last authors is justified by seeds pretreatment which was the scarification before sowing. This pretreatment directly exposed the embryo to external temperature and increases it water absorption. Seed pretreatment methods would also influence the emergence rate of M. oleifera seedlings.

Depending on provenance, the germination rate varies from $72.59 \pm 4.35 \%$ for provenance 3 (Adamawa) to $79.99 \pm$ $4.35 \%$ for provenance 2 (North) (Figure $1 \mathrm{~b}$ ). No significant difference $(\mathrm{P}>0.05)$ is shown between traitements. These results are similar to those obtained in the Sudano-Sahelian zone of Cameroon by Baye-Niwah and Mapongmetsem (2015).
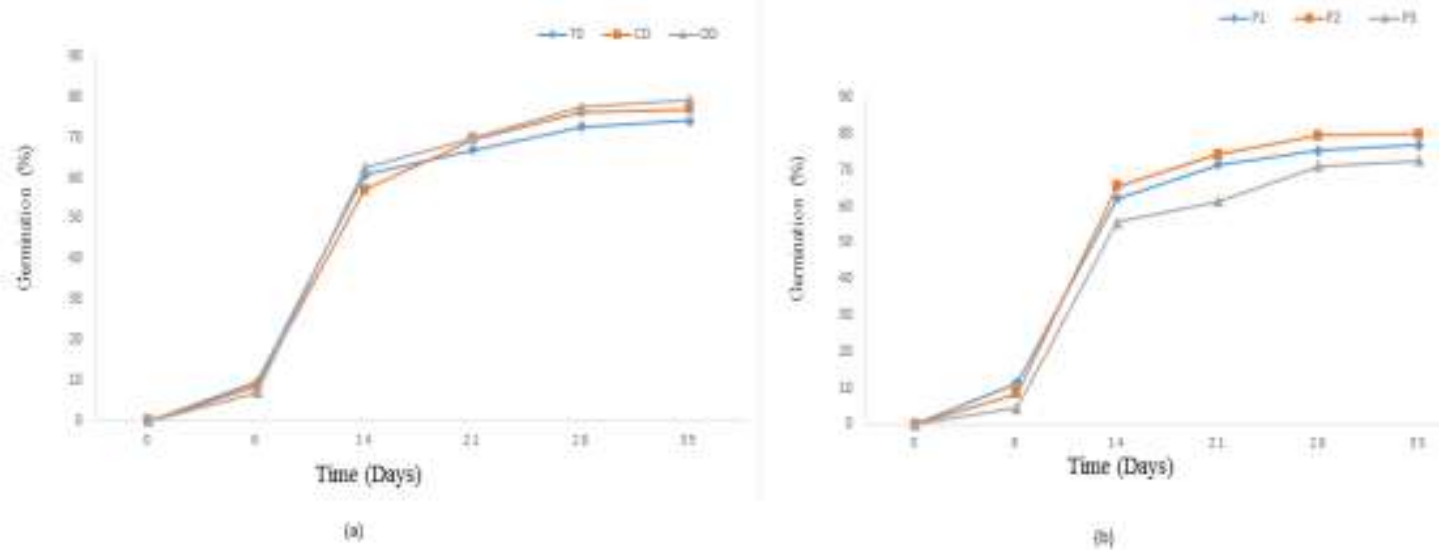

\begin{tabular}{|l|l|}
\hline T0 $=$ Control & P1 = Far-North \\
\hline CD = Composted dung & P2 = North \\
\hline DD = Dried dung & P3 = Adamawa \\
\hline
\end{tabular}

Figure 1:-Germination rate of $M$. oleifera seeds according to the type of fertilizer (a) and the provenance (b)

\section{Height growth of $M$. oleifera:-}

After 105 days, the height of $M$. oleifera plants according to the type of organic fertilizer varies from $14.78 \pm 2.23$ $\mathrm{cm}$ for the untreated plants to $26.63 \pm 1.79 \mathrm{~cm}$ for the plants treated with the composted dung (Figure 2a). A significant difference between the plants is revealed $(\mathrm{P}<0.05)$. Composted and dried dung were significantly different from the control but statistically identical to each other. These results are partially similar to those of Asante et al. (2012) in Ghana on the response of M. oleifera to several types of amendments. These authors showed that compost contains higher percentage of organic matter than other types of fertilizers. This organic matter is available in the long term, thus facilitating good drainage, as well as content of growth hormones such as auxins, gibberellins and cytokinins. Furthermore, it increases the cation exchange capacity, the biomass of microorganisms and their activities (Mulaji, 2011).

Regarding the seeds origin of the plants, the height of the plants after 105 days varies from $19.30 \pm 1.90 \mathrm{~cm}$ for provenance 3 (Adamawa) to $23.09 \pm 1.93 \mathrm{~cm}$ for provenance 2 (North) (Fig 2b), with a non-significant difference 
(P>0.05). These results are in agreement with those of Förster et al. (2015) in Germany on the growth of different ecotypes of M. oleifera.

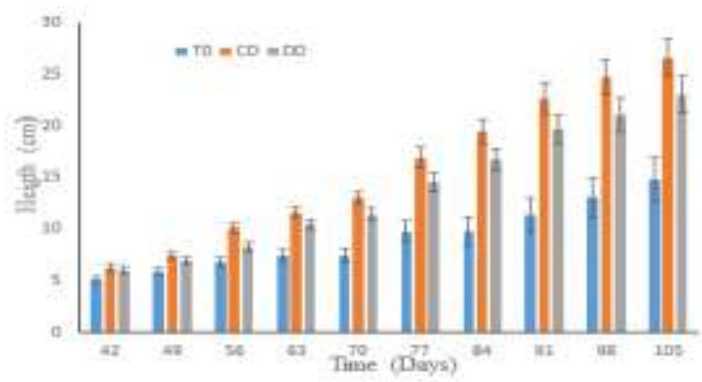

(a)

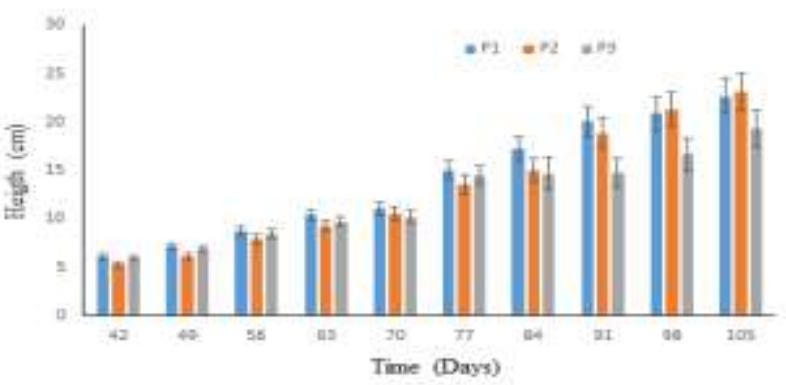

\begin{tabular}{|l|l|}
\hline T0 = Control & P1 = Far-North \\
\hline$C D=$ Composted dung & $\mathrm{P} 2=$ North \\
\hline $\mathrm{DD}=$ Dried dung & $\mathrm{P} 3=$ Adamawa \\
\hline
\end{tabular}

Figure 2: Growth in height of M. oleifera according to different types of fertilization (a) and provenances (b).

Depending to manure-provenance interaction, the height of the seedlings oscillates between $12.34 \pm 4.09 \mathrm{~cm}$ for provenance 2 (North) untreated and $29 \pm 2.84 \mathrm{~cm}$ for provenance 1 (Far North) treated with composted dung (Table $\mathrm{I})$, with a non significant difference $(\mathrm{P}>0.05)$.

Table I:-Interaction between origin and fertilizer on height growth of M. oleifera plants.

\begin{tabular}{|c|c|c|c|c|}
\hline Ori & Control & $\mathrm{CD}$ & DD & Average \\
\hline P1 & $13.27 \pm 3.47$ & $29 \pm 2.84$ & $25 \pm 3.38$ & $22.42 \pm 3.23$ \\
\hline P2 & $12.34 \pm 4.09$ & $28.81 \pm 3.38$ & $26.03 \pm 2.74$ & $22.39 \pm 3.40$ \\
\hline P3 & $18.72 \pm 3.47$ & $22.08 \pm 3.07$ & $18.02 \pm 3.3$ & $19.60 \pm 3.28$ \\
\hline $\mathrm{Ave}$ & $14.77 \pm 3.67$ & $26.63 \pm 3.09$ & $23.01 \pm 3.14$ & $21.47 \pm 3.30$ \\
\hline
\end{tabular}

\section{Radial growth of $M$. oleifera:-}

According to different amendements, radial growth of seedlings 105 days after sowing varied from $4.46 \pm 0.42 \mathrm{~mm}$ for control to $7.11 \pm 0.35 \mathrm{~mm}$ for composted dung treatment with an average of $6.02 \pm 0.65 \mathrm{~mm}$ (Fig 3a), with a significant difference $(\mathrm{P}<0.01)$ between the types of fertilization. These results are partially I accordance with those of Asante et al. (2012) in Ghana on the growth of M. oleifera following various types of amendments. Composted and dried dung were significantly different from the control but statistically identical to each other.

Depending on provenance, the diameter of the stems varies from $5.98 \pm 0.37 \mathrm{~mm}$ for provenance 1 (Far-North) to $6.31 \pm 0.39 \mathrm{~mm}$ for provenance 2 (North) (Fig.3b), with a non significant difference (P>0.05). These results are in according with those of Patricio et al. (2012) in Philippine on the adaptability of several provenances of M.oleifera.

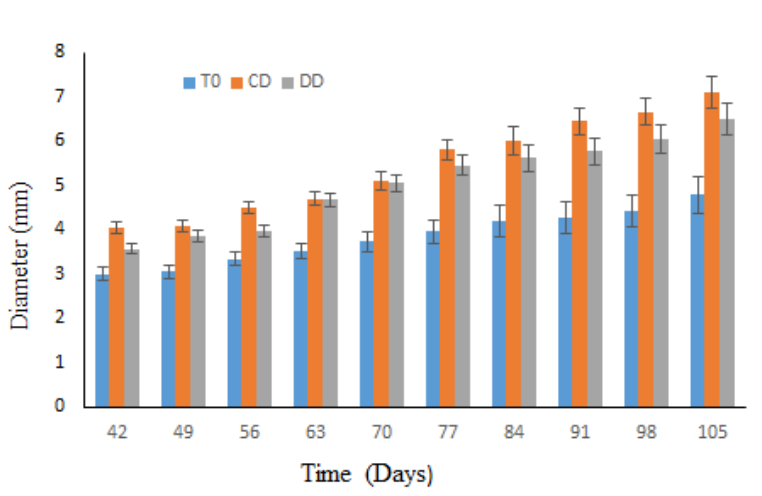

(a)

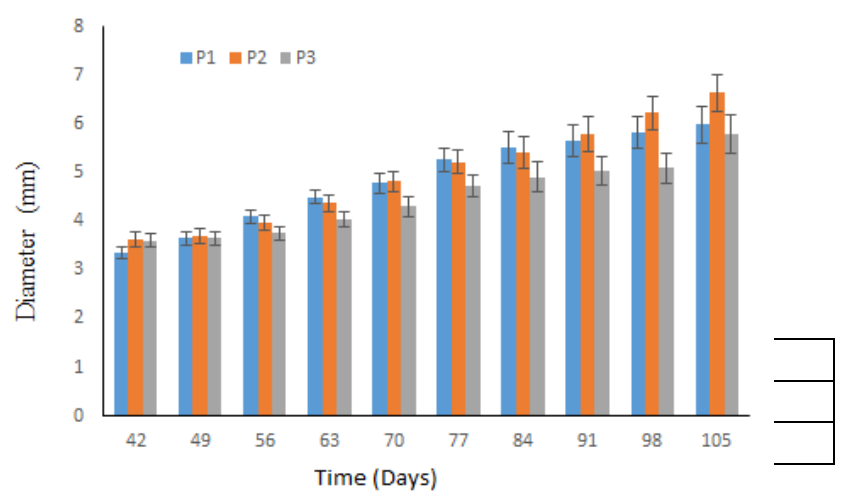

(b)

In terms of provenance-fertılization interaction, diametrıc growth varıed between $3.80 \pm 0.81 \mathrm{~mm}$ tor provenance 2

(North), control, and $8.12 \pm 0.67 \mathrm{~mm}$ for provenance 2 treated with composted dung (Table II). There is no 
significant difference $(\mathrm{P}>0.05)$. These results are in agreement with those of Baiyeriet al. (2015) in Nigeria on the growth performance and nutritional quality of three $M$. oleifera accessions at variable levels of manure and watering intervals

TableII: Origin-fertilizer Interaction on radial growth of $M$. oleiferaplants.

\begin{tabular}{|c|c|c|c|c|}
\hline Origin/manure & Control & $\mathrm{CD}$ & DD & Average \\
\hline P1 & $4.04 \pm 0.69$ & $7.21 \pm 0.56$ & $6.70 \pm 0.67$ & $5.98 \pm 0.64$ \\
\hline $\mathrm{P} 2$ & $3.86 \pm 0.81$ & $8.12 \pm 0.67$ & $6.95 \pm 0.55$ & $6.31 \pm 0.67$ \\
\hline $\mathrm{P} 3$ & $5.48 \pm 0.69$ & $6.00 \pm 0.61$ & $5.91 \pm 0.65$ & $5.79 \pm 0.65$ \\
\hline Average & $4.46 \pm 0.73$ & $7.11 \pm 0.61$ & $6.52 \pm 0.62$ & $6.02 \pm 0.65$ \\
\hline
\end{tabular}

\section{Number of leaves:-}

At 105 days after planting, the number of leaves ranged from $8.21 \pm 0.51$ in untreated seedlings to $10.32 \pm 0.39$ for those treated with the composted dung with $9.24 \pm 0.74$ as average (Fig. 4a). The analysis of variance indicates a significant difference $(\mathrm{P}<0.001)$. These results are in agreement with those of Adebayo et al. (2011) on the evaluation of several organic amendments including compost on the development of $M$. oleifera in Nigeria

On the same date, the number of leaves according to provenance varies from $8.21 \pm 0.51$ for seedlings from provenance 1 (Far North) to $10.32 \pm 0.39$ for those from provenance 3 (Adamawa) (Fig. 4b), but with no significant difference $(\mathrm{P}>0.05)$. These results are in agreement with those of Ndubuakuet al. (2015) in Nigeria who tested the effect of chicken droppings on the growth of 3 provenances of $M$. oleifera seeds.

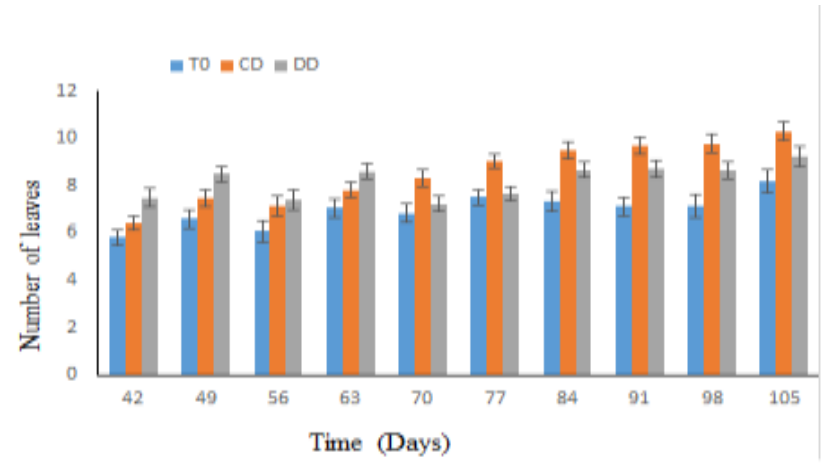

(a)

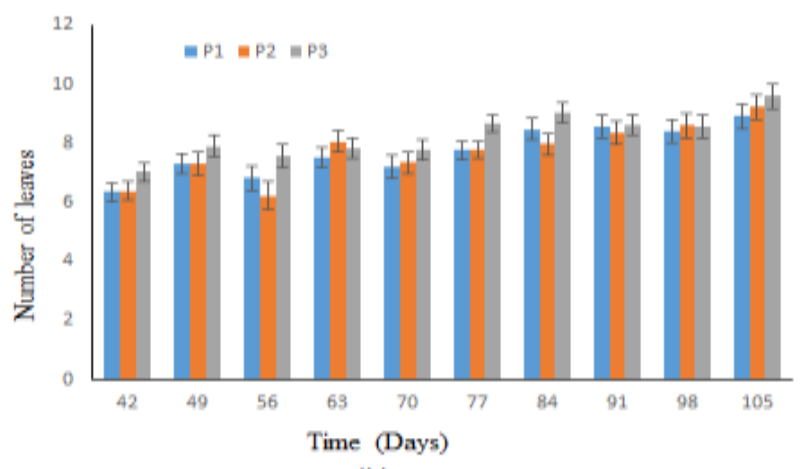

(b)

\begin{tabular}{|l|l|}
\hline T0 = Control & P1 = Far-North \\
\hline $\mathrm{CD}=$ Composted dung & P2 = North \\
\hline DD = Dried dung & P3 = Adamawa \\
\hline
\end{tabular}

Figure 4:- Number of leaves of $M$. oleifera according to type of fertilizer (a) and provenance (b)

For manure-provenance interaction, the number of leaves per seedling oscillates between $7.44 \pm 0.76$ in untreated seedlings of provenance 1 and $10.62 \pm 0.62$ in those of the same provenance fattened with the composted cow dung (Table III), with no significant difference $(\mathrm{P}>0.05)$. These results are in agreement with those of Larwanou et al. (2014) in Niger on the interaction between fertilizers and water regime applied to the growth of M. oleifera.

Table III:-Origin-fertilization interaction on the number of leaves of M. oleiferaplants

\begin{tabular}{|l|l|l|l|l|}
\hline Origin/manure & Control & CD & DD & Average \\
\hline P1 & $7.44 \pm 0,76$ & $10.62 \pm 0.62$ & $8.72 \pm 0.76$ & $\mathbf{8 . 9 2} \pm \mathbf{0 . 7 1}$ \\
\hline P2 & $7.44 \pm 1,08$ & $10.42 \pm 0.74$ & $9.82 \pm 0.6$ & $\mathbf{9 . 2 2} \pm \mathbf{0 . 8 0}$ \\
\hline P3 & $9.76 \pm 0,78$ & $9.91 \pm 0.67$ & $9.15 \pm 0.72$ & $\mathbf{9 . 6 0} \pm \mathbf{0 . 7 2}$ \\
\hline Average & $\mathbf{8 . 2 1} \pm \mathbf{0 , 8 7}$ & $\mathbf{1 0 . 3 1} \pm \mathbf{0 . 6 7}$ & $\mathbf{9 . 2 3} \pm \mathbf{0 . 6 9}$ & $\mathbf{9 . 2 4} \pm \mathbf{0 . 7 4}$ \\
\hline
\end{tabular}

\section{Survival of $M$. oleifera plants in the field:-}

Regarding the type of fertilizer, the survival rate of the plants at the end of the test oscillates between $47 \pm 10.84 \%$ for control to $75.55 \pm 9.72 \%$ in dried dung treatment (Fig. 5a) with a significant difference $(\mathrm{P}<0.01)$ between fertilizer types. 
Depending on the origin of the plants, the survival rate ranges from $61.11 \pm 9.42 \%$ for provenance 2 (North) to $75.55 \pm 9,16 \%$ for provenance 3 (Adamawa) (Fig. 5b), with no significant difference (P>0.05). Kiragu et al. (2015) in Kenya observed survival rates of less than $50 \%$ on $M$. oleifera seedlings grown following different planting methods. Cutting does not allow for a sufficiently deep and rapid development of roots comparatively to direct seeding. The seeding method influences the survival of $M$. oleifera plants.

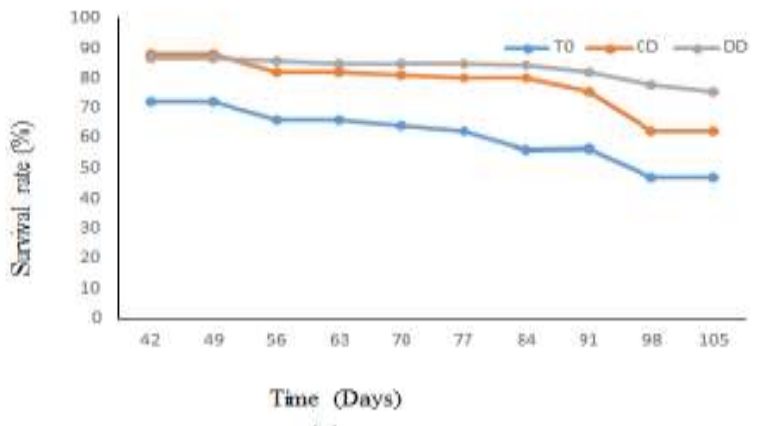

(a)

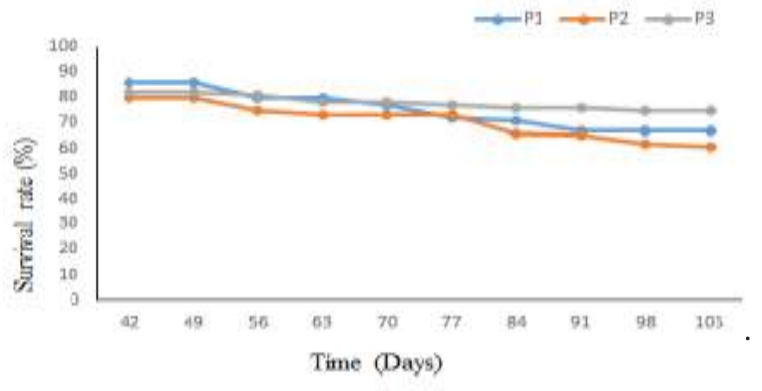

(b)

The interaction fertilitzer-provenance revealed the survival rate that overlaps between $33.33 \pm 9.60 \%$ for control provenance 2 (North) and $86.71 \pm 10.84$ for provenance 1 (Far North) treated with dried dung (Table IV). No significant difference $(0.38>0.05)$ was revealed for this interaction. These results are in agreement with those of Costa et al. (2015) in Brazil on the interaction between the density of M. oleifera seedlings at different seasons (Winter and Autumn).

Table IV: Origin-fertilization interaction for $M$. oleifera survival rate

\begin{tabular}{|l|l|l|l|l|}
\hline Origin/manure & Control & CD & DD & Average \\
\hline P1 & $60 \pm 10,80$ & $63.33 \pm 10,84$ & $86.71 \pm 10.84$ & $\mathbf{7 0 . 0 1} \pm \mathbf{1 0 . 8 2}$ \\
\hline P2 & $33.33 \pm 9.60$ & $60 \pm 9.78$ & $67.33 \pm 10.56$ & $\mathbf{5 3 . 5 5} \pm \mathbf{9 . 9 8}$ \\
\hline P3 & $66.66 \pm 10.84$ & $76.66 \pm 10.12$ & $70 \pm 10.20$ & $\mathbf{7 1 . 1 0} \pm \mathbf{1 0 . 3 8}$ \\
\hline Average & $\mathbf{5 3 . 3 3} \pm \mathbf{1 0 . 4 1}$ & $\mathbf{6 6 . 6 6} \pm \mathbf{1 0 . 2 4}$ & $\mathbf{7 4 . 6 8} \pm \mathbf{1 0 . 5 3}$ & $\mathbf{6 4 . 8 8} \pm \mathbf{1 0 . 3 9}$ \\
\hline
\end{tabular}

\section{Conclusion:-}

The purpose of this study was to evaluate the growth and development performance of Moringa oleifera according to the type of organic fertilizers and provenances.Both (space) for the organic fertilizer types and the provenances, the average germination rate was $76.53 \pm 4.35 \%$. The type of organic fertilizers has a significant influence on the growth of $M$. oleifera and composted dung was the most effective treatment. Provenances do not reveal any significant differences. The two foreign provenances (Far North and North) were adapted very well to the climate of the high savannas of Guinea climate and the environment is favorable to blossoming.(space) Each of tree provenances(Far North, North and Adamawa) treated with composted cow dung can therefore be recommended to growers to improve the yield of $M$. oleifera.

\section{References:-}

1. Akintoye H.A., Olufolaji A.O., Aina M.T.O. \&Shokalu A.O., 2011. Assessment of organic amendements on vegetative development and nutrient uptake of Moringaoleifera Lam in the nursey. Asian Journal of Plant Sciences, 10 (1): 74-79.

2. Allard S., 2009. Moringa(http://fleurdevie.over-blog.fr).

3. Asante W.J., Kwame O.B, \&Baatuuwie N.B., 2012.Initial growth response of Moringaoleifera seedlings to different soil amendments.African Journal of Agricultural Research, 7(45): 6082-6086.

4. Baiyeri K.P., Apeh P., Stevens C.G., Ndukwe O.O., Aba1 S.C \&Otitoju G.T., 2015. Growth performance and nutrient quality of three Moringa noleiferaaccessions grown as potplant under varied manure rates and watering intervals.African Journal of Biotechnology, 14 (24): 1996-2004.

5. Banque Mondiale., 2014. Euvrer pour le monde sans pauvreté.

6. http://www.banquemondiale.org/omd/pauvrete_faim.html.Visité le 10-07-16. 
7. Barakat H. \&Ghazal G. A., 2016. Physicochemical Properties of MoringaoleiferaSeeds and Their Edible Oil Cultivated at Different Regions in Egypt.Food and Nutrition Sciences, 7: 472-484.

8. Bayé-Niwah C., 2015. Caractérisation agroforestière de MoringaoleiferaLam. (Moringaceae) en zone Soudanosahélienne du Cameroun. Thèse de Doctorat PhD, Faculté des Sciences. Université de Ngaoundéré, Cameroun. $197 \mathrm{p}$.

9. Dlamini M.M., Mupangwa J.F., Bhebhe E. \&Dlamini B.J., 2014. The growth performance, biomass production and nutritive value of three moringa provenances in Luyengo, Swaziland.UNISWA Journal of Agriculture, 17: 1-13.

10. Ede A. E., Ndubuaku U. M. \&Baiyeri K. P., 2015. Media effects on Emergence and growth of Moringa (Moringaoleifera Lam) seedlings in the nursery. American Journal of Experimental Agriculture, 7 (3): 182-189.

11. Fagbohun A., Afolayan M., Ikokoh P., Olajide O., Adebiyi A., Fatokun O., Ayesanmi A. \&Orishadipe A., 2013. Isolation and characterization studies of Moringaoleifera root starch as a potential pharmaceutical and industrial biomaterial. International Journal of Chemistry and Applications, 5 (2): 117-126.

12. FAO, FIDA \& PAM, 2015. L'état de l'insécurité alimentaire dans le monde. Objectifs internationaux 2015 de réduction de la faim: des progrès inégaux. Organisation des nations unies pour l'alimentation et l'agriculture. Rome, Italie 66p.

13. Fuglie L.J., 2001. Combating malnutrition with Moringa.(Ed. Fuglie, LJ). CWS, Darkar, Senegal 37p.

14. Förster N., Ulrichs C., Schreinert M., Arnol N., Schimd R. \&Mewis I., 2015. Ecotype variability in growth and secondary metabolitprofil in Moringaoleifera: Impact of sulfur and water availibility. Journal of Agriculture and Food Chemistry, 63(11): 2852-2861.

15. Godinez-Oviedo A., Guemes-Vera N. \& Acevedo-Sandoval O.A., 2016. Nutritional and phytochemical composition of Moringaoleifera Lam. and its potential use as nutraceutical plant: A Review.Pakistan Journal of Nutrition, 15 (4): 397-405.

16. Hessou C., Kakaï R.G., Assogbadjo A., Odjo T. \&Sinsin B., 2009. Test de germination des graines de Caesalpiniabonduc(L.) Roxb au Bénin.International Journal of Biological and Chemical Sciences, 3 (2): 310 317.

17. Kasolo J.N., Bimenya G.S., Ojok L., Ochieng L., \&Ogwal-okeng J.W., 2010. Phytochemicals and uses of Moringaoleiferaleaves in Ugandan rural communities. Journal of Medicinal Plants Research, 4:753-755.

18. Larwanou M., Adamou M.M. \&Abasse T., 2014.Effects of fertilization and watering regimes on early growth and leaf biomass production for two food tree species in the Sahel: Moringa oleifera Lam. and AdansoniadigitataL. Journal of Agricultural Science and Applications, 3(4): 82-88.

19. Letoudze R. 1968. Flore du Cameroun 8. Ulmacées, Urticacées. Mus. Natl. Hist. Nat., Paris.

20. 222p. (this is the page of the reference 19)

21. Madi P.O., Bourou S. \&Woin N., 2012.Utilisations et importances socio-économiques de

22. MoringaoleiferaLam. en zone de savanes d'Afrique Centrale. Cas de la ville de Maroua au Nord-Cameroun. Journal of AppliedBiosciences, 60: 4421- 4432.

23. Malo T., 2014. Effet de la fertilisation sur la croissance et la production de Moringaoleiferalocal et MoringaoleiferaPKM-1 dans la Région des Cascades (Burkina Faso). Mémoire Master, Université de BoboDioulasso, Burkina-Faso. 68p.

24. Mulaji K.C., 2011. Utilisation des composts de biodéchets ménagers pour l'amélioration de la fertilité des sols acides de la province de Kinshasa (République Démocratique du Congo). Thèse de Doctorat, Université de Liège- Gembloux Agro-Biotechnologie. 220p.

25. Ndubuaku U.M., Ede A.E., Baiyeri K.P. \&Ezeaku P.I., 2015. Application of poultry manure and its Effect on growth and performance of potted Moringa (MoringaoleiferaLam) plants raised for urban dwellers' use. American Journal of Plant Nutrition and Fertilization Technology, 5 (1):33-39.

26. Njehoya C.A., Sali B., Awono P.M. \&Bouba H., 2014.Évaluation du potentiel de germination de Moringaoleifera dans la zone soudano-guinéenne du Cameroun. Journal of Applied Biosciences, 74: 61416148.

27. Olson M.E., 2001.Introduction to Moringa family.In: Fuglie, L. J. (ed.). Themiracle tree: the multiple attributes ofMoringaoleiferaCWS. Dakar, Sénégal.pp 11 -28.

28. OMS, 2016. Données et analyses pour les objectifs de développement durable relatifs à la santé. Cité sur www.who.int. visité le 15-02-2016

29. Pahla I., Tagwira F., Muzemu1 S. \&Chitamba J., 2013. Effects of soil type and manure level on the establishment and growth of Moringa oleifera. International Journal of Agriculture and Forestry, 3(6): 226230 . 
30. Patricio H.G. Palada M.C \& Ebert A.W., 2012.Adaptability and horticultural characterization of Moringaaccessions under Central Philippines conditions. SEAVEG2012 Regional Symposium, 24-26 January 2012. 11p.

31. Quashie A.A.M., Yawa A. \&Tchezoum., 2009. Étude de la germination de Moringaoleifera LAM». Afrique Science, 5 (3): 1-8.

32. Rajangam J., Azahakia M.R.S., Thangaraj T., Vijayakumar A. \&Muthukrishan N., 2001. Production et utilisation du Moringaen Inde: la situation actuelle, 9p.

33. Rapport OMD, 2010. Rapport régional de progrès des objectifs du millénaire pour le développement, région de l'Adamaoua. 31p.

34. Subha G. \& Tapas B., 2013. Health promoting components with natural medicinal and nutritional facts of Moringaoleifera: A review. International Journal of Pharmaceutical Research and Bioscience, 2 (6): $284-286$.

35. Suhag M., 2016.Potential of biofertilizers to replace chemical fertilizers.International Advanced Research Journal in Science, Engineering and Technology, 3 (5): 1588-2314.

36. Weber J., Karczewska A., Drozd J., Lieznar M., Lieznar S., Jamroz E. \&Kocowiez A., 2007. Agricultural and ecological aspects of sandy soil as affected by the application of municipal solid waste composts. Soil Biology and Biochemistry, 39: 1294-1302.

37. Yerima B.P.K., Ayuk G.M., EnangR.K., Guehjung N. \&

38. Tiamgne Y.A, 2016. Germination and early seedling growth of MoringaoleiferaLam with different seeds soaking time and substrates at the Yongka Western Highlands Research Garden Park (YWHRGP) NkwenBamenda, North-West Cameroon. American Journal of Plant Sciences 7: 2173-2185.

39. Youssef M., 2016. Impact of biofertilizers on growth and yield of Moringa oleifera Lam. AlAzhar Journal of Agriculture and Research, 26: 127-130 